\title{
Effect of a legume cover crop on carbon storage and erosion in an Ultisol under maize cultivation in southern Benin
}

\author{
Bernard Barthès', Anastase Azontonde², Eric Blanchart', Cyril Girardin', Cécile \\ Villenave ${ }^{4}$, Robert Oliver', Christian Feller' \\ 'Laboratoire MOST (IRD-CIRAD), BP 64501. 34394 Montpellier cedex 5, France \\ ${ }^{2}$ Laboratnire des Sciences du Sol. Eaux et Environnement (LSSEE, ex-CENAP), 01 BP 988. \\ Cotonou, Benin \\ ${ }^{3}$ Laboratoire BIOMCO. Centre INRA-INAPG. BP 1, 78850 Thiverval-Grignon, France \\ ${ }^{4}$ Unité de Recherche IBIS (IRD), Laboratoire d'Ecologie Microbienne. UMR CNRS 5557. \\ Université Lyon 1.43 Bd du 11 Novembre 1918, 69622 Villeurbanne cedex. France
}

Address for correspondence: B. Barthès <harthes(a)mpl.ird.fr>

\section{Résumé}

Dans les régions tropicales à forte population, il n'est plus possible d'assurer avec les jachères de longue durée une gestion durable des matières organiques du sol (SOM). Parmi les alternatives, la culture d'engrais vert, en particulier du Mucuna pruriens, semble intéressante : elle peut maintenir la fertilité du sol en même temps que limiter l'érosion. Cette étude vise l'estimation du stockage du C dans le sol et l'érosion dans un réseau de parcelles d'érosion sur un Ultisol sablo-limoneux du Bénin, à la suite d’une expérimentation qui a duré 12 ans de trois systèmes de culture du maïs comportant le travail manuel du sol : $\mathrm{T}=$ culture traditionnelle, $\mathrm{NPK}=$ apport d'engrais minćraux. $\mathrm{M}=$ idem associé à Mucuna .

En T. NPK. M. les variations de stock de $C$ du sol sur $40 \mathrm{~cm}$ furent restectivement $-0.2 .+0.2 \mathrm{et}+1.3 \mathrm{MgC} \mathrm{ha}{ }^{-1} \mathrm{an}^{-1}$. La biomasse annuelle moyenne de résidus restituée au sol s’élève respectivement à $3.5,6.4$ et $10.0 \mathrm{Mg} \mathrm{C} \mathrm{ha-1} \mathrm{an}^{-1}$. Elle provient surtout des adventices en T $(72 \%)$. du maïs en NPK $(75 \%)$ et du maïs et du Mucuna en M ( $50 \%$ chacun).

En T, NPK et M, le ruissellement annuel moyen fut 28,12 et $8 \%$, les pertes en terres moyennes annuelles s élèvent à $34,9.3 \mathrm{ct} 2.9 \mathrm{t} / \mathrm{ha} / \mathrm{an}$. Enfin le $\mathrm{C}$ érodé a été estimé à 0.3 .0 .1 et 0.1 tha/an, respectivement. Le Mucina a contribué à la gestion durable du sol grâce à la production d'une grande quantité de hiomasse au ras du sol et par la protection du sol. Cependant, du point de vue du changement climatique global, des estimations grossières ont montré que les émissions d'oxydes d'azote $\left(\mathrm{N}_{2} \mathrm{O}\right)$ provenant de la fixation de $\mathrm{N}$ par le Mucuna équilibre l'enrichissement du sol en carbone. Ceci souligne la nécessité de mesurer en parrallèle les flux de $\mathrm{N}_{2} \mathrm{O}$ pour estimer le bénéfice réel de légumineuses comme plantes de couvertures .

Mots-clés : Bénin, bilan organique du sol, biomasse des résidus de culture, érosion, Mucuna, plante de couverture.

\begin{abstract}
Sustainable management of soil organic matter (SOM) through long-term natural fallow is difficult in densely populated tropical areas. Among alternative practices to ensure sustainable management of SOM, living mulches with legume cover crops (e.g. Mucuna pruriens) are promising. In addition, legumes maintain soil fertility and control erosion. A 12-year experiment was conducted to assess soil carbon (C) storage and erosion in runoff plots established on a sandy loam Ultisol (Benin) for three maize-based (Zea mays) cropping
\end{abstract}


systems with manual tillage: no-input traditional cultivation (T), fertilizer input (NPK), and with mucuna $(\mathrm{M})$ cover. Changes in soil $\mathrm{C}$ stock for $0-40 \mathrm{~cm}$ depth were $-0.2,+0.2$ and $+1.3 \mathrm{MgCha}{ }^{-1} \mathrm{yr}^{-1}$ for $\mathrm{T}, \mathrm{NPK}$ and $\mathrm{M}$, respectively. Mean annual residue biomass $\mathrm{C}$ returned to the soil was $3.5,6.4$ and $10.0 \mathrm{MgC} \mathrm{ha}^{-1} \mathrm{yr}^{-1}$, respectively. The principal source was weeds in T $(72 \%)$, maize in NPK (75\%), and maize and mucuna in M (ca. 50\% each). Average annual runoff rates were $0.28,0.12$ and $0.08 \mathrm{~mm} \mathrm{~mm}^{-1}$, average annual soil losses were 34.0 , 9.3 and $2.9 \mathrm{Mg} \mathrm{ha}^{-1} \mathrm{yr}^{-1}$, and eroded $\mathrm{C}$ were estimated at $0.3,0.1$ and $0.1 \mathrm{MgC} \mathrm{ha}{ }^{-1} \mathrm{yr}^{-1}$ for $\mathrm{T}$, NPK and M treatments, respectively. Thus, mucuna live mulch contributed to sustainable soil management, particularly through large residue biomass and soil conservation.

However, nitrous oxide $\left(\mathrm{N}_{2} \mathrm{O}\right)$ emissions resulting from nitrogen $(\mathrm{N})$ supply by mucuna may partly offset soil $\mathrm{C}$ enrichment, and underlines the need for measurement of $\mathrm{N}_{2} \mathrm{O}$ fluxes in order to assess the real environmental benefits of leguminous cover crops.

\section{Key Words}

Soil organic carbon, residue biomass, erosion, cover crop, mucuna, Benin, West Africa

\section{Introduction}

Soil organic matter (SOM) management is recognized as a cornerstone for successful farming in most tropical areas with or without the application of mineral fertilizers (Merckx et al., 2001). Several experiments have demonstrated the direct or indirect positive effects of SOM on chemical, physical and biological properties of soil related to plant response (Sanchez, 1976; Pieri, 1991). Moreover, SOM is an essential reservoir of carbon (C), and SOM management can have significant implications on the global $C^{\prime}$ balance and thus on climate change (Craswell and Lefroy, 2001). In many rural areas of the tropics, the environmental challenge consists of reducing deforestation, increasing organic matter storage in cultivated soils, and reducing soil erosion. Therefore, under the economical conditions prevailing in developing countries, maintaining soil fertility and meeting the environmental challenge require land-use practices that include high levels of organic inputs and soil organic ( sequestration (Feller et al., 2001).

Natural fallowing has long been the main practice to maintain soil fertility in tropical areas. However, as its effects only become significant after a period of at least 5 years, natural fallowing is no longer possible in the context of increasing population. Such is precisely the case in southern Benin, where the population density is 300 to 400 inhab km-2 (Azontonde, 1993). The benefits of legume-based cover crops in Africa (in regions with annual rainfall $>800 \mathrm{~mm}$ ) as an alternative to natural fallow, to control weeds and soil erosion, and enrich soil organic matter and $\mathrm{N}$ are widely recognized (Voelkner, 1979; Raunet et al., 1999; Carsky et al., 2001). In southwestern Nigeria, higher maize (Zea mays) yields were obtained in live mulch plots under ('entrosema pubescens or Psophocarpus palustris than in conventionally tilled and no-till plots for four consecutive seasons (Akobundu, 1980).

The effect of relay-cropping maize through Mucuna pruriens (var. utilis) was assessed in southern Benin from 1988 to 1999 in terms of plant productivity and soil fertility (Azontonde, 1993; Azontonde et al., 1998). The relay-cropping system (M) was compared with traditional maize cropping system without any input ( $\mathrm{T}$ ), and with a maize cropping system with mineral fertilizers (NPK). This paper focuses on changes in soil ('during the period of the experiment in relation to residue biomass $\mathrm{C}$ returned to the soil, runoff and suil erosion losses and loss of $\mathrm{C}^{\prime}$ with erosion.

\section{Materials and methods}

Description of the site and treatments 
The experiment was conducted from 1988 to 1999 at an experimental farm at Agonkanmey $\left(6^{\circ} 24^{\circ} \mathrm{N}, 2^{\circ} 20^{\circ} \mathrm{E}\right)$, near (otonou in southern Benin in an area of low plateaux. The climate is subhumid-tropical with two rainy scasons (March-July and September-November). Mean annual rainfall is $1200 \mathrm{~mm}$ and mean annual temperature is $27^{\circ} \mathrm{C}$. The soils are classified as Typic Kandiustult (Soil Survey Staff. 1994) or Dystric Nitisols (FAO-ISRIC-ISSS, 1998). and have a sandy loam surface layer overlying a sandy clay loam layer at about $50 \mathrm{~cm}$ depth. Most of the land is cultivated to maize (Zea mays), beans (Vigna sp.), cassava (Manihot csculenta) or peanuts (Arachis hypogea), often associated with oil palm (Elacis guineensis). The study was conducted on three $30 \times 8 \mathrm{~m}$ plots on a $4 \%$ slope. These demonstration plots were not replicated, as it is usually difficult in long-term experiments (Shang and Tiessen. 2000), especially when these include runoff plots. Threc cropping systems were compared: T (traditional), maize without any input; NPK. maize with mineral fertilizers $\left(200 \mathrm{~kg} \mathrm{ha}^{-1}\right.$ of NPK 15-15-15, and $100 \mathrm{~kg} \mathrm{ha}^{-1}$ of urea); M, relay-cropping of maize and a legume cover crop, Mucuna pruriens var. utilis, with no fertilizer. Maize (var. DMR) was cropped during the first rainy season with shallow hoe tillage by hand (hoeing depth was about $5 \mathrm{~cm}$ ). In $M$ plot. maize was sown through the mucuna mulch from the previous year. Mucuna was sown one month later, and once maize had been harvested. its growth as a relay-crop continued until the end of the second (short) rainy scason. During this short rainy season, the $T$ and NPK treatments were maintained as natural fallow. Additional information on the site and soil properties has been provided by Azontonde (1993) and Azontonde et al. (1998).

\section{Soil and plant sampling}

Undisturbed soil profile samples were collected: (i) in March, June, August and October 1988 and 1995, at 18 locations per plot for 0-10, 10-20 and 20-40 cm depths, using 0.2- $\mathrm{dm}^{3}$ soil cores, and (ii) in November 1999 at three locations per plot for $0-10$ and $10-20 \mathrm{~cm}$ depths in two replicates, and for 20-30, 30-40 and $50-60 \mathrm{~cm}$ depths in one replicate, using $0.5-\mathrm{dm}^{3}$ soil cores. Soil samples were also obtained with a knife for different depths along the profile walls. Soil bulk density (Db) was determined after oven-drying core samples, whereas the other samples were air-dried, sieved $(2 \mathrm{~mm})$ and ground $(<0.2 \mathrm{~mm})$ for $\mathrm{C}$ and $\mathrm{N}$ analyses.

Aboveground biomass of maize and mucuna was determined every year from five replicates $(1 \times 1 \mathrm{~m})$ at maize harvest (August) and at mucuna maximum growth (October), respectively. In 1995, following the same pattern, roots of maize and mucuna were collected for 0-10.1020 and $20-40 \mathrm{~cm}$ depths, and hand-sorted (Azontonde $\mathrm{ct}$ al., 1998). Annual root biomass was calculated using the ratio of below- to aboveground biomass determined in 1995, and the annual aboveground biomass. Sampling of the aboveground biomass of weed was done in November 1999 at nine locations per plot, using a $0.25 \times 0.25-\mathrm{m}$ frame. Litter was simultaneously and similarly sampled. Root sampling was also carried out in November 1999 on six $0.25 \times 0.25 \times 0.30-\mathrm{m}$ monoliths per plot: monoliths were cut into three layers (corresponding to $0-10,10-20$ and $20-30 \mathrm{~cm}$ depths), and visible roots were hand-sorted. With respect to the vegetation cover, we assumed that roots and litter sampled in T and NPK originated from weeds, whereas those sampled in $\mathrm{M}$ originated from mucuna. All plant samples were dried at $70^{\circ} \mathrm{C}$, weighed for biomass measurement, and finely ground for $\mathrm{C}$ determination.

\section{Carbon and nitrogen determination, and other analyses}

Total C content (Ct) of soil samples collected in 1988 and 1995 was determined by the Walkley and Black method (WB), and total $\mathrm{N}$ content ( $\mathrm{Nt}$ ) by the Kjehldahl method. Both $\mathrm{Ct}$ and $\mathrm{Nt}$ of soil samples collected in 1999 were determined by the dry combustion method (DC) using an Elemental Analyzer (Carlo Erba NA 1500). The Ct was analyzed on 
60 samples using both WB and DC methods, leading to a relationship $(r=0.971)$ that was used to convert WB data into DC data. All Ct data are thereafter expressed on a DC basis. The $\mathrm{C}$ content of plant samples was determined by dry combustion using an Elemental Analyzer (CHN LECO 600).

Particle-size analysis was performed by the pipette method after removal of organic matter with $\mathrm{H}_{2} \mathrm{O}_{2}$ and dispersion by $\mathrm{Na}$-hexametaphosphate. Soil pH in water was determined using a 1:2.5 volumetric soil:solution ratio.

\section{Determinations of runoff, soil losses and eroded carbon}

Each plot was surrounded by half-buried metal sheets and fitted out with a collector draining runoff and sediments toward two covered tanks set up in series. When the first tank was full, additional flow moved through a multi-divisor tank into the second tank, both with a capacity of $3-\mathrm{m}^{3}$. Runoff and soil loss data were collected from 1993 to 1997.

Runoff amount $\left(\mathrm{m}^{3}\right)$ was assessed on every plot after each rainfall event or sequence of events, by measuring the volume of water in each tank and multiplying it by a coefficient depending on divisors. This runoff amount was converted to depth on the basis of the plot area. Annual runoff rate $\left(\mathrm{mm} \mathrm{mm}^{-1}\right)$ was defined as the ratio of annual runoff depth to annual rainfall, and mean annual runoff rate as the ratio of runoff depth to rainfall over five years.

The amount of dry coarse sediments $(\mathrm{Mg})$ was deduced by weighing wet coarse sediments collected in the first tank, and oven-drying the aliquots. The quantity of suspended sediments $(\mathrm{Mg})$ was assessed by flocculation and oven drying of aliquots collected from each tank. Annual soil losses ( $\mathrm{Mg} \mathrm{ha}{ }^{-1} \mathrm{yr}^{-1}$ ) were computed as the sum of dry-coarse and -suspended sediments over one year, and averaged over tive years to calculate mean annual soil losses.

Annual eroded $\mathrm{C}\left(\mathrm{MgC} \mathrm{ha}{ }^{-1} \mathrm{yr}^{-1}\right)$ was calculated as the product of annual soil losses by $\mathrm{C}$ content of sediments. Sediment $C$ content was not measured, but was estimated as the product of soil $\mathrm{Ct}$ (at $0-10 \mathrm{~cm}$ depth, for the year under consideration) by an enrichment ratio (Starr et al., 2000). Soil $\mathrm{Cl}$ for the year under consideration was interpolated from soil Ct measurements carried out in 1988, 1995 and 1999. The enrichment ratio, defined as the ratio of $\mathrm{Ct}$ in sediments to that in the soil $(0-10 \mathrm{~cm}$ depth), was estimated from the data in the literature: on light-textured Ultisols and Oxisols under maize cultivation (with mineral fertilizers) in southern and northern Ivory Coast, with 2100- and 1350-mm annual rainfall, respectively, C enrichment ratios measured in runoff plots by Roose (1980a, 1980b) were 1.9 (7\% slope) and 1.4 (3\% slope), respectively. Thus, C enrichment ratio of 1.6 was assumed for maize plots ( $\mathrm{T}$ and $\mathrm{NPK}$ ). In the absence of literature data regarding cover crops, $\mathrm{C}$ enrichment ratio under maize-mucuna $(M)$ was found similar to those measured in runoff plots having comparable soil cover conditions: for two light-textured Oxisols under bush Savannas in northern Ivory Coast, with 1200- and 1350-mm annual rainfall, respectively, C enrichment ratio measured by Roose and Bertrand (1972) and Roose (1980b) was 2.6 (4\% slope) and 3.4 (3\% slope), respectively; and for a sandy Ultisol under banana plantation in southern Ivory Coast (14\% slope, $1800-\mathrm{mm}$ annual rainfall), C enrichment ratio was 3.0 (Roose and Godefroy, 1977). Averaging these data, $\mathrm{C}$ enrichment ratio of 3.0 was assumed for maize-mucuna $(M)$ rotation. Dissolved $C$ in runoff was neither measured nor taken into consideration.

\section{Siatistical analyses}

Differences in mean $\mathrm{Ct}$ and $\mathrm{Ct}$ stocks were tested by a Student unpaired $\mathrm{t}$-test. Differences in mean annual runoff rates, soil losses and eroded $C$ were tested by a paired $t$-test. In both cases, no assumptions were made on normality and variance equality (Dagnélie, 1975). 
Table 1. Soil clay content, $\mathrm{pH}$ in water, total carbon content $\mathrm{Ct}, \mathrm{C}: \mathrm{N}$ ratio, and total carbon stock in 1988 and 1999 (mean \pm standard deviation when available).

\begin{tabular}{|c|c|c|c|c|c|c|c|}
\hline & \multirow{2}{*}{$\begin{array}{l}\text { Depth } \\
(\mathrm{cm})\end{array}$} & \multicolumn{2}{|c|}{$\mathrm{T}$} & \multicolumn{2}{|c|}{ NPK } & \multicolumn{2}{|c|}{$M$} \\
\hline & & 1988 & 1999 & 1988 & 1999 & 1988 & 1999 \\
\hline $\begin{array}{c}\text { Clay } \\
\left(\mathrm{g} \mathrm{kg}^{-1}\right)\end{array}$ & $\begin{array}{l}0-10 \\
10-20\end{array}$ & $\begin{array}{c}147 \pm 1 \\
\text { nd }\end{array}$ & $\begin{array}{l}216 \\
339\end{array}$ & $\begin{array}{c}111 \pm 6 \\
\text { nd }\end{array}$ & $\begin{array}{l}128 \\
198\end{array}$ & $\begin{array}{c}127 \pm 6 \\
\text { nd }\end{array}$ & $\begin{array}{l}136 \\
179\end{array}$ \\
\hline $\mathrm{pH}$ & $\begin{array}{l}0-10 \\
10-20\end{array}$ & $\begin{array}{l}5.6 \pm 0.1 \\
5.4 \pm 0.2\end{array}$ & $\begin{array}{l}5.1 \\
4.7\end{array}$ & $\begin{array}{l}5.6 \pm 0.1 \\
5.4 \pm 0.2\end{array}$ & $\begin{array}{l}5.2 \\
5.0\end{array}$ & $\begin{array}{l}5.2 \pm 0.1 \\
5.1 \pm 0.2\end{array}$ & $\begin{array}{l}5.0 \\
5.0\end{array}$ \\
\hline $\begin{array}{c}(\mathrm{i} \\
\left(\mathrm{gkg}^{-1}\right)\end{array}$ & $\begin{array}{l}0-10 \\
10-20 \\
20-30^{\mathrm{a}} \\
30-40^{\mathrm{a}} \\
50-60\end{array}$ & $\begin{array}{l}5.5 \pm 0.2 \\
4.6 \pm 0.3 \\
4.1 \pm 0.2 \\
\text { nd }\end{array}$ & $\begin{array}{l}5.3 \pm 0.1 \\
4.0 \pm 0.7 \\
3.5 \pm 0.5 \\
3.2 \pm 0.1 \\
2.4 \pm 0.1\end{array}$ & $\begin{array}{l}5.4 \pm 0.1 \\
4.8 \pm 0.4 \\
4.0 \pm 0.4 \\
\text { nd }\end{array}$ & $\begin{array}{l}6.7 \pm 1.8 \\
3.8 \pm 1.2 \\
3.6 \pm 1.1 \\
4.1 \pm 0.7 \\
3.5 \pm 1.8\end{array}$ & $\begin{array}{l}5.2 \pm 0.1 \\
4.8 \pm 0.4 \\
4.6 \pm 0.3 \\
\text { nd }\end{array}$ & $\begin{array}{r}11.5 \pm 2.0 \\
7.3 \pm 0.9 \\
4.4 \pm 0.1 \\
4.2 \pm 0.2 \\
3.3 \pm 0.5\end{array}$ \\
\hline$C: N$ & $\begin{array}{l}0-10 \\
10-20 \\
20-30^{\mathrm{a}} \\
30-40^{\mathrm{a}} \\
50-60\end{array}$ & $\begin{array}{l}10.2 \pm 1.0 \\
10.9 \pm 1.4 \\
11.4 \pm 1.2 \\
\text { nd }\end{array}$ & $\begin{array}{r}12.2 \pm 0.4 \\
10.1 \pm 0.6 \\
8.7 \pm 0.5 \\
8.2 \pm 0.8 \\
7.0 \pm 0.4\end{array}$ & $\begin{array}{l}10.8 \pm 0.5 \\
10.7 \pm 1.8 \\
10.6 \pm 1.9 \\
\text { nd }\end{array}$ & $\begin{array}{r}11.3 \pm 0.1 \\
9.9 \pm 0.7 \\
9.3 \pm 1.0 \\
8.8 \pm 1.4 \\
8.8 \pm 3.2\end{array}$ & $\begin{array}{l}11.5 \pm 0.5 \\
12.0 \pm 1.8 \\
12.8 \pm 1.7 \\
\text { nd }\end{array}$ & $\begin{array}{r}11.9 \pm 0.8 \\
11.6 \pm 0.8 \\
10.0 \pm 1.2 \\
8.9 \pm 1.3 \\
8.1 \pm 1.4\end{array}$ \\
\hline $\begin{array}{c}\mathrm{Ct} \text { stock } \\
\left(\mathrm{MgCh} \mathrm{ha}^{-1}\right)\end{array}$ & $\begin{array}{l}0-10 \\
0-20 \\
0-40 \\
0-60\end{array}$ & $\begin{array}{l}7.7 \pm 0.7 \\
13.6 \pm 0.9 \\
25.9 \pm 1.5 \\
\text { nd }\end{array}$ & $\begin{array}{r}8.4 \pm 0.3 \\
14.5 \pm 0.4 \\
24.2 \pm 0.5 \\
32.0 \pm 0.3\end{array}$ & $\begin{array}{l}7.3 \pm 0.5 \\
14.6 \pm 1.0 \\
27.0 \pm 1.8 \\
\text { nd }\end{array}$ & $\begin{array}{l}10.6 \pm 3.4 \\
17.0 \pm 3.9 \\
28.8 \pm 5.7 \\
39.7 \pm 3.6\end{array}$ & $\begin{array}{l}6.8 \pm 0.3 \\
13.8 \pm 0.8 \\
27.7 \pm 1.7 \\
\text { nd }\end{array}$ & $\begin{array}{l}17.4 \pm 3.3 \\
28.7 \pm 3.9 \\
41.4 \pm 4.9 \\
51.7 \pm 4.1\end{array}$ \\
\hline
\end{tabular}

nd: not determined

a $20-40 \mathrm{~cm}$ in 1988

Table 3. Annual runoff rates, soil losses and $\mathrm{C}$ erosion.

\begin{tabular}{|c|c|c|c|c|c|c|c|c|c|c|}
\hline \multirow[t]{2}{*}{ Year } & \multirow[t]{2}{*}{$\begin{array}{l}\text { Rainfall } \\
\left(m m y^{-1}\right)\end{array}$} & \multicolumn{3}{|c|}{$\begin{array}{l}\text { Runoff rate } \\
\left(\mathrm{mm} \mathrm{mm} \mathrm{mm}^{-1}\right)\end{array}$} & \multicolumn{3}{|c|}{$\begin{array}{c}\text { Soil losses } \\
\left(\mathrm{Mg} \mathrm{ha}^{-1} \mathrm{yr}^{-1}\right)\end{array}$} & \multicolumn{3}{|c|}{$\begin{array}{c}\text { C erosion } \\
\left(\mathrm{MgC} \mathrm{ha}^{-1} \mathrm{yr}^{-1}\right)\end{array}$} \\
\hline & & $\mathrm{T}$ & NPK & $M$ & $T$ & NPK & $M$ & $\mathrm{~T}$ & NPK & M \\
\hline 1993 & 1288 & 0.30 & 0.13 & 0.09 & 41.5 & 9.8 & 3.1 & 0.4 & 0.1 & 0.1 \\
\hline 1994 & 1027 & 0.20 & 0.10 & 0.06 & 31.2 & 8.2 & 2.2 & 0.3 & 0.1 & 0.1 \\
\hline 1995 & 1000 & 0.16 & 0.08 & 0.04 & 10.6 & 3.8 & 1.3 & 0.1 & 0.0 & 0.0 \\
\hline 1996 & 1126 & 0.25 & 0.12 & 0.08 & 40.4 & 8.9 & 2.5 & 0.3 & 0.1 & 0.1 \\
\hline 1997 & 1558 & 0.40 & 0.15 & 0.11 & 46.3 & 15.6 & 5.5 & 0.4 & 0.2 & 0.2 \\
\hline Mean & 1200 & 0.28 & 0.12 & 0.08 & 34.0 & 9.3 & 2.9 & 0.3 & 0.1 & 0.1 \\
\hline $\mathrm{SD}^{\mathrm{a}}$ & 230 & 0.09 & 0.03 & 0.03 & 14.2 & 4.2 & 1.6 & 0.1 & 0.0 & 0.1 \\
\hline
\end{tabular}

${ }^{\text {a }} \mathrm{SD}$ : standard deviation 


\section{Results}

General properties of soils (Table 1)

The clay $(<2 \mu \mathrm{m})$ content of the soil ranged between 110 and $150 \mathrm{~g} \mathrm{~kg}^{-1}$ for $0-10 \mathrm{~cm}$ depth in 1988, and it increased between 1988 and 1999 in T $(50 \%)$ but not in NPK and M treatments (increase $<15 \%$ ). The clay content also increased with depth. Mureover, clay content in 1999 was higher at $0-10 \mathrm{~cm}$ in T than at $10-20 \mathrm{~cm}$ in NPK and M treatments. The sand $(>50 \mu \mathrm{m})$ content was between 600 and $800 \mathrm{~g} \mathrm{~kg}^{-1}$ to $20 \mathrm{~cm}$ depth, mainly in the form of coarse sand $(>200 \mu \mathrm{m})$ (data not shown). Soil pH was acidic $(<6)$ and decreased between 1988 and 1999, especially in T and NPK treatments (-0.5 over a decade).

\section{Soil carbon (Table 1)}

Total soil carbon content $\mathrm{Ct}\left(\mathrm{g} \mathrm{C} \mathrm{kg}^{-1}\right.$ soil) was determined through 18- and three-replicate sampling in March 1988 and November 1999, respectively. The validity of the latter was assessed using 18-replicate sampling done in October 1995 as a reference: following Dagnélie (1975) and Shang and Tiessen (2000), at 95\% confidence level, irrespective of the plot and the depth, three-replicate sampling in 1995 would have led to a less than $8 \%$ relative error in $\mathrm{C} t$ estimation. Thus, $\mathrm{Ct}$ determined in 1999 by three-replicate sampling was representative of the mean value of the plot. Similarly, $\mathrm{Ct}$ stock $\left(\mathrm{Mg} \mathrm{C}^{-1}\right)$ estimated in November 1999 was representative of the large area.

Differences in $\mathrm{Ct}$ between plots were negligible $(<2 \%$ at $0-20 \mathrm{~cm})$ in March 1988. Between March 1988 and November 1999, $\mathrm{Ct}$ increased considerably at $0-20 \mathrm{~cm}$ depth in $\mathrm{M}(+90 \%$, $\mathrm{p}<0.01)$ but changed slightly in T $(-8 \%)$ and NPK $(+3 \%)$, and for $20-40 \mathrm{~cm}$ depth (changes $<20 \%$ ). In November 1999, and as a consequence, $\mathrm{Ct}$ at $0-20 \mathrm{~cm}$ depth was much greater in $M$ than in $T(+100 \%, p<0.01)$ and NPK $(+80 \%, p<0.05)$ treatments. Differences between plots were rather small below this depth, as were differences between NPK and T $(<30 \%$ in general) treatments.

Changes in $\mathrm{Ct}$ stock $(\mathrm{MgCha})$ for $0-40 \mathrm{~cm}$ depth were similar showing small initial differences between plots (<7\%); between March 1988 and November 1999, slight changes in T and NPK $(<15 \%)$ treatments but a considerable increase in $M(+50 \%, p<0.01)$; higher final $\mathrm{C} t$ stock in $\mathrm{M}$ than in $\mathrm{T}(+70 \%, \mathrm{p}<0.01)$ and $\mathrm{NPK}(+45 \%, \mathrm{p}<0.05)$ treatments. Stock of $\mathrm{Ct}$ for $0-40 \mathrm{~cm}$ depth finally attained the value of 24,29 and $41 \mathrm{Mg} \mathrm{C}$ ha ${ }^{-1}$ in $\mathrm{T}$, NPK and $\mathrm{M}$, respectively. Between 1988 and 1999, mean ( \pm standard deviation) annual changes in $\mathrm{Ct}$ stock were $+0.1( \pm 0.1),+0.2( \pm 0.4)$ and $+1.4( \pm 0.4) \mathrm{MgCha}^{-1} \mathrm{yr}^{-1}$ in T, NPK and M, respectively, for 0 to $20 \mathrm{~cm}$ depth; and $-0.2( \pm 0.1),+0.2( \pm 0.5)$ and +1.3 $( \pm 0.5) \mathrm{MgC} \mathrm{ha}^{-1} \mathrm{yr}^{-1}$, respectively, for 0 to $40 \mathrm{~cm}$ depth.

\section{Residue biomass (Table 2)}

Average annual residue biomass (dry matter) returned to the soil in T, NPK and M was 8.0, 13.0 and $19.9 \mathrm{Mg} \mathrm{ha}^{-1} \mathrm{yr}^{-1}$, with 35,72 and $82 \%$ of aboveground biomass, respectively. Mean annual residue $\mathrm{C}$ added was $3.5,6.4$ and $10.0 \mathrm{MgCha}^{-1} \mathrm{yr}^{-1}$, with 39,74 and $84 \%$ as aboveground biomass, respectively (aboveground biomass had a slightly more $\mathrm{C}$ content than roots). Returned C mainly originated from weeds in $\mathrm{T}(55 \%$ as roots and $17 \%$ as aboveground biomass), which represented 44 and $92 \%$ of aboveground and belowground residue $C$, respectively. In contrast, returned $C$ in NPK was mainly from maize $(61 \%$ as aboveground biomass and $14 \%$ as roots). In $\mathrm{M}$, maize and mucuna accounted for similar amounts of residue C, either as aboveground biomass (about $40 \%$ each) or roots ( $8 \%$ each). Moreover, maize residue biomass C was of the same order of magnitude in NPK and M (ca. $5 \mathrm{MgC} \mathrm{ha} \mathrm{yr}^{-1}$ ) treatments. 
Table 2. Residue biomass returned to the soil (mean \pm standard deviation).

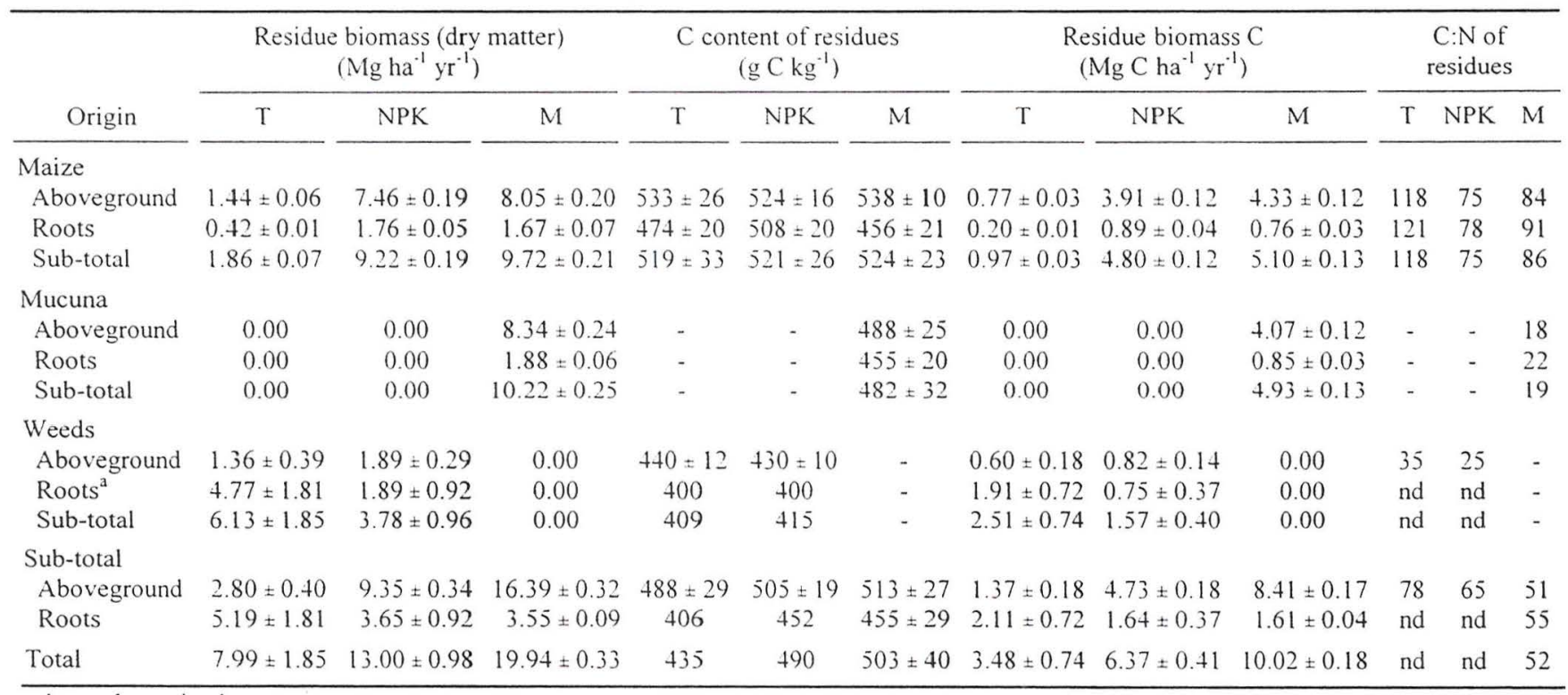

nd: not determined

${ }^{a} 0-30 \mathrm{~cm}$; data resulting from sampling carried out in November 1999 , assuming that roots collected in $\mathrm{T}$ and NPK were weed roots only and had a C content of $400 \mathrm{~g} \mathrm{C} \mathrm{kg}^{-1}$ 
Runoff, soil losses and eroded carbon (Table 3)

Annual rainfall ranged between 1000 and $1558 \mathrm{~mm}$, and averaged $1200 \mathrm{~mm}$ between 1993 and 1997. Mean annual runoff rate in T, NPK and M treatments was $0.28,0.12$ and $0.08 \mathrm{~mm} \mathrm{~mm}^{-1}$, and mean annual soil losses was $34.0,9.3$ and $2.9 \mathrm{Mg} \mathrm{ha}^{-1} \mathrm{yr}^{-1}$, respectively. Using $C$ enrichment ratios of sediments determined in similar soil and climate conditions (Roose, 1980a, 1980 b), mean eroded $\mathrm{C}$ was estimated at $0.3,0.1$ and $0.1 \mathrm{MgC}^{-1} \mathrm{ha}^{-1} \mathrm{yr}^{-1}$ in $\mathrm{T}$, NPK and $M$ treatments, respectively. In plots vulnerable to erosion, eroded $C$ was thus of the same order of magnitude as changes in $\mathrm{Ct}$ stock for $0.40 \mathrm{~cm}$ depth: $-0.3 \mathrm{vs}$. $-0.2 \mathrm{MgC} \mathrm{ha}^{-1} \mathrm{yr}^{-1}$ in $\mathrm{T}$, and $-0.1 \mathrm{vs} .+0.2 \mathrm{MgC}^{1} \mathrm{ha}^{-1} \mathrm{yr}^{-1}$ in NPK. In contrast, eroded $\mathrm{C}$ in $\mathrm{M}$ was negligible compared with changes in $\mathrm{Cl}^{1}$ stock: $-0.1 \mathrm{vs} .+1.3 \mathrm{Mg} \mathrm{C}^{-1} \mathrm{yr}^{-1}$. Moreover, mean annual runoff rate and soil losses were significantly more in $T$ than in NPK and more in NPK than in $M$; and eroded $C$ was more in T than in NPK and $M(p<0.01)$ treatments. Additionally, mean annual runoff rate, soil losses and eroded $\mathrm{C}$ increased with the increase in annual rainfall.

\section{Discussion}

\section{Changes in soil carbon}

At the end of our experiment, Ct stock for $0-40 \mathrm{~cm}$ depth was $24 \mathrm{Mg} \mathrm{C}^{-1}$ under unfertilized maize, $29 \mathrm{Mg} \mathrm{C}$ ha ${ }^{-1}$ under fertilized maize, and $41 \mathrm{Mg}$ ( 'ha ${ }^{-1}$ under maize-mucuna rotation. Elsewhere in southern Benin and in similar soil conditions, Djegui el al. (1992) reported Ct stocks for $0-35 \mathrm{~cm}$ depth at $27 \mathrm{Mg} \mathrm{C}$ ha ${ }^{-1}$ under oil palm plantation, $30 \mathrm{Mg} \mathrm{C}^{-1}$ under food crops (with fallow), and $48 \mathrm{MgC} \mathrm{ha}{ }^{-1}$ under forest.

The data on $\mathrm{Ct}$ stock presented herein are consistent with other published data (Table 4). For an Alfisol in southwestern Nigeria, rates of $+0.2 \mathrm{Mg} \mathrm{C}^{-1} \mathrm{yr}^{-1}$ were recorded for $0-10 \mathrm{~cm}$ depth for fertilized maize (Lal, 2000), vs. $+0.3 \mathrm{Mg} \mathrm{C} \mathrm{ha}^{-1} \mathrm{yr}^{-1}$ for NPK; in Brazilian Ultisols and Oxisols, rates of around $+1 \mathrm{MgC} \mathrm{ha}^{-1} \mathrm{yr}^{-1}$ were measured for $0-20 \mathrm{~cm}$ depth under longterm no-till cropping systems (Bayer et al.. 2001; Sá et al., 2001), vs. $+1.4 \mathrm{Mg} \mathrm{C}^{-1}$ in $\mathrm{M}$; in a Nigerian Alfisol, rates beyond $+2 \mathrm{MgC} \mathrm{ha}{ }^{-1} \mathrm{yr}^{-1}$ have even been measured for $0-20 \mathrm{~cm}$ depth under a two-year Pueraria cover (Lal, 1998). These data confirm that residue mulching increases C $\mathrm{C}$ stock in tropical soils, especially in cropping systems including legume cover crops.

\section{Residue biomass}

The high rates of $\mathrm{Ct}$ increase in $\mathrm{M}$ resulted first from high residue biomass returned to the soil, which averaged $20 \mathrm{Mg} \mathrm{ha}^{-1} \mathrm{yr}^{-1}$ (dry matter). The aboveground biomass of mucuna was $8 \mathrm{Mg} \mathrm{ha}^{-1} \mathrm{y}^{-1}$, within the range of published data: 6-7 Mg ha ${ }^{-1} \mathrm{yr}^{-1}$ in one-year mucuna fallows in Nigeria (Vanlauwe et al., 2000) and an average of $11 \mathrm{Mg} \mathrm{ha}^{-1} \mathrm{yr}^{-1}$ in mucuna-maize systems in Honduras (> 2000-mm annual rainfall; Triomphe, 1996b). The ratio of change in Ct stock to residue $\mathrm{C}$ measured in these plots also agreed with data in the literature: in a 12 year no-till maize-legume rotations on a sandy clay loam Ultisol in Brazil, $\mathrm{Ct}$ stock increase for $0-17.5 \mathrm{~cm}$ depth represented $11-15 \%$ of aboveground residue C (Bayer et al., 2001), vs. $15 \%$ in $\mathrm{M}$ (and $5 \%$ in NPK). In contrast, in long-term no-till cereal-legume rotations on clayey Oxisols also in Brazil, the increase in $\mathrm{Ct}$ stock for $0-40 \mathrm{~cm}$ depth represented $22-25 \%$ of total residue C (Sá et al., 2001), vs. 12\% in M (and 3\% in NPK). This difference confirms the role of clay content for $\mathrm{C}$ sequestration through the development of stable aggregates and hence organic matter protection (Feller and Beare, 1997).

In plots that were left under natural fallow during the short rainy season, weeds represented an important proportion of residue biomass, i.e. $77 \%$ in T and $29 \%$ in NPK. Weeds represented about $50 \%$ of the aboveground residue biomass in $\mathrm{T}$, as was also the case in non- 
Table 4. Compared values of annual changes in $\mathrm{Ct}$ stock under various tropical cropping systems including reduced or no tillage.

\begin{tabular}{|c|c|c|c|}
\hline $\begin{array}{l}\text { Country } \\
\text { and soil type }\end{array}$ & $\begin{array}{l}\text { Cropping system } \\
\text { (and duration, in } \mathrm{yr} \text { ) }\end{array}$ & $\begin{array}{l}\text { Change in Ct stock } \\
\left(\mathrm{MgCha}^{-1} \mathrm{yr}^{-1}\right)\end{array}$ & Reference \\
\hline & & \multicolumn{2}{|l|}{ for $0.20 \mathrm{~cm}$ depth } \\
\hline Nigeria, Alfisol & Pucrariasp. (2) & +2.1 & Lal (1998) \\
\hline Benin, Ultisol & maize-mucuna (11) & +1.4 & this study \\
\hline Brazil, clayey Oxisol & cereals and soybean $(10.22)$ & +1.0 & Sá et al. $(2001)$ \\
\hline Brazil, clay loam Ultisol & Cajanus cajan-maize (12) & $+0.9^{2}$ & Bayer et al. (2001) \\
\hline Nigeria, Alfisol & Stylosanthes sp. (2) & +0.4 & Lal (1998) \\
\hline Benin, Ultisol & fertilized maize (11) & +0.2 & this study \\
\hline Nigeria, Alfisol & Centrosemasp. (2) & +0.1 & Lal (1998) \\
\hline \multirow[t]{2}{*}{ Benin, Ultisol } & non-fertilized maize (11) & +0.1 & this study \\
\hline & & \multicolumn{2}{|l|}{ for $0-10 \mathrm{~cm}$ depth } \\
\hline Benin, Ultisol & maize-m & +1.0 & this study \\
\hline Nigeria, Alfisol & Cajanus cajan-maize (3) & +0.7 & Lal $(2000)$ \\
\hline Honduras, various soils & mucuna-maize $(1$ to 15$)$ & $+0.5^{b}$ & Triomphe (1996a) \\
\hline Benin. Ultisol & fertilized maize (11) & +0.3 & this study \\
\hline Nigeria, Alfisol & fertilized maize (3) & +0.2 & Lal $(2000)$ \\
\hline Benin, Utisol & non-fertilized maize (II) & +0.1 & this study \\
\hline
\end{tabular}

for $0-17.5 \mathrm{~cm}$ depth

"from $+0.2 \mathrm{to}+1.4 \mathrm{Mg}\left(\mathrm{ha}^{-1} \mathrm{yr}^{-1}\right.$. depending on the site

Figure 1. Relationship between mean annual $\mathrm{C}$ erosion $\left(\mathrm{MgCh} \mathrm{ha}^{-1} \mathrm{yr}^{-1}\right)$ and the product of mean annual soil losses $\left(\mathrm{Mg} \mathrm{ha}^{-1} \mathrm{yr}^{-1}\right)$ into $\left(1\right.$ stock of bulk soil at $0-30 \mathrm{~cm}\left(\mathrm{Mg} \mathrm{C} \mathrm{ha}^{-1}\right)$ (data from Table 5).

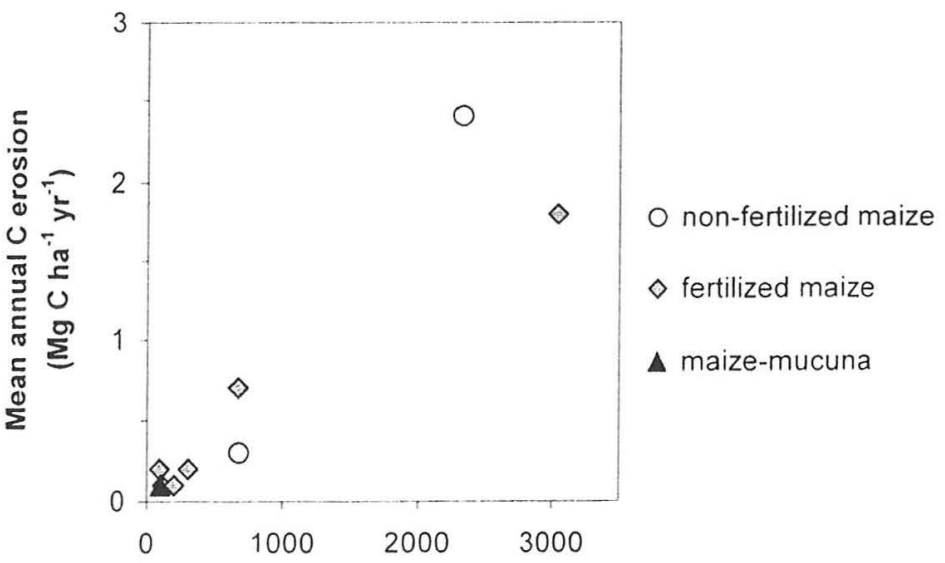

Mean annual soil losses $\left(\mathrm{Mg} \mathrm{ha}^{-1} \mathrm{yr}^{-1}\right)$

$x$ Ct stock at $0-30 \mathrm{~cm}\left(\mathrm{MgC} \mathrm{ha}^{-1}\right)$ 
fertilized maize plots studied in Nigeria (Kirchhof and Salako, 2000). These data underline the need for systematic measurements of weed biomass when it represents a noticeable proportion of biomass returned to the soil. In our experiment, weeds were sampled on one day only, and it is likely that it led to some uncertainties. Weed biomass was negligible in $\mathrm{M}$ : proportions of aboveground residue biomass for maize, mucuna and weeds were 49,51 and ()\%, respectively. Similarly, these proportions were 49, 42 and $9 \%$, respectively, in one-year maize-mucuna plots studied in Nigeria (Kirchhof and Salako, 2000). Indeed, Carsky et al. (2001) reported that weed suppression was often cited as the reason for the adoption of mucuna fallow systems in Africa.

\section{Nitrous oxide emissions}

Use of nitrogenous fertilizers also impacts nitrous oxide $\left(\mathrm{N}_{2} \mathrm{O}\right)$ emissions, which can be roughly estimated using equation (1) (Bouwman, 1996):

$\mathrm{N}-\mathrm{N}_{2} \mathrm{O}$ emissions $\left(\mathrm{kg} \mathrm{ha}^{-1} \mathrm{yr}^{-1}\right)=1+\left[0.0125 \times \mathrm{N}\right.$-fertilizer $\left.\left(\mathrm{kg} \mathrm{ha}^{-1} \mathrm{yr}^{-1}\right)\right]$.

In NPK, $\mathrm{N}$ fertilizer was used at the rate of $76 \mathrm{~kg} \mathrm{~N}^{-1} \mathrm{yr}^{-1}$ (Azontonde et al., 1998). Following equation (1), it resulted in $2-\mathrm{kg} \mathrm{N}^{-\mathrm{N}_{2}} \mathrm{O} \mathrm{ha}^{-1} \mathrm{yr}^{-1}$ emissions. As the global warming potential of $\mathrm{N}_{2} \mathrm{O}$ is about 300 times that of $\mathrm{CO}_{2}\left(\mathrm{IPCC}, 2001\right.$ ), these $\mathrm{N}_{2} \mathrm{O}$ emissions were equivalent to more than $0.2-\mathrm{MgC}^{-}-\mathrm{C}^{\prime} \mathrm{O}_{2} \mathrm{ha}^{-1} \mathrm{yr}^{-1}$ emissions, and thus offset $\mathrm{Ct}$ increase $\left(0.2 \mathrm{MgC}^{-1} \mathrm{yr}^{-1}\right)$.

In $\mathrm{M}$, mucuna residues supplied the soil with more than $250 \mathrm{~kg} \mathrm{~N} \mathrm{hat}^{-1} \mathrm{yr}^{-1}$ (Azontonde et al., 1998). In this case, equation (1) led to an overestimation of $\mathrm{N}_{2} \mathrm{O}$ emissions, as it was established from a set of experiments excluding legume cover crops, which provide $N$ that is less directly available than mineral fertilizers. However, it may give an order of magnitude:

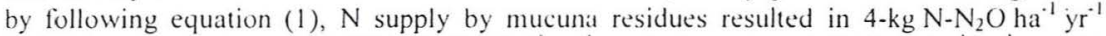
emissions, equivalent to $0.5-\mathrm{MgC}-\mathrm{CO}_{2} \mathrm{ha}^{-1} \mathrm{yr}^{-1}$ emissions (vs. $1.3 \mathrm{MgC} \mathrm{ha}^{-1} \mathrm{yr}^{-1}$ as Cl increase). Though overestimated, these data indicate that from an environmental point of view, $\mathrm{Ct}$ increase in soils under legume cover crops could be partly offset by $\mathrm{N}_{2} \mathrm{O}$ emissions.

\section{Runoff, soil losses and eroded curbon}

As compared with T, mean annual runoff rate and soil losses were 57 and $73 \%$ less in NPK, respectively, and were 71 and $91 \%$ less in $M$, respectively. Protection of the soil surface by vegetation and residues dissipates kinetic energy of rainfall and has an important influence on the reduction of runoff and erosion (Wischmeier and Smith, 1978). Thus, groundcover by mucuna mulch was probably the main reason for less runoff and soil losses in $M$ than in $T$ and NPK treatments. Similarly but to a lesser extent, it is likely that due to large biomass, fertilized maize provided a better groundcover than unfertilized maize. Additionally, residue return determines an increase in SOM which favours aggregate stability (Feller et al., 1996), thus preventing detachment of easily transportable particles, and thereby reducing surface clogging, runoff' and erosion (Le Bissonnais, 1996) Therefore, higher C't also resulted in less runoff and erosion in M than in NPK, and also less in NPK than in T treatment.

With respect to runoff plots from tropical areas cropped with maize (or sorghum), comparisons with published data show that annual runoff rate was high $\left(>0.25 \mathrm{~mm} \mathrm{~mm}^{-1}\right)$ in $\mathrm{T}$ and under humid conditions $(2100-\mathrm{mm}$ annual rainfall); soil losses were high ( $\left.>20 \mathrm{Mg} \mathrm{ha}^{-1} \mathrm{yr}^{-1}\right)$ under humid or semi-arid conditions $(500-\mathrm{mm}$ annual rainfall) and in nonfertilized plots (Table 5). In contrast, runoff rate was low $\left(<0.10 \mathrm{~mm} \mathrm{~mm}^{-1}\right)$ on steep slopes with clayey soils (Kenya) and under maize-mucuna (M); soil losses were low $\left(<5 \mathrm{Mg} \mathrm{ha}^{-1} \mathrm{yr}^{-1}\right)$ in $\mathrm{M}$ treatment. Thus, runoff and erosion increased with increase in annual rainfall and/or with a decrease in soil surface cover (absence of mulch, non-fertilized plots, semi-arid conditions), in accordance with usual observations (Wischmeier and Smith, 1978; 
Table 5. Compared values of annual runoff rate, soil losses and $\mathrm{C}$ erosion from runoff plots cropped with maize (or sorghum) in tropical areas.

\begin{tabular}{|c|c|c|c|c|c|c|c|c|}
\hline Country & $\begin{array}{l}\text { Rainfall } \\
\left(\mathrm{mm} \mathrm{yr}^{-1}\right)\end{array}$ & $\begin{array}{l}\text { Slope } \\
(\%)\end{array}$ & Soil type & $\begin{array}{l}\text { Ct stock } \\
\left(\mathrm{Mg} \mathrm{C} \mathrm{ha}^{-1}\right)\end{array}$ & $\begin{array}{l}\text { Runoff rate } \\
\left(\mathrm{mm} \mathrm{mm}^{-1}\right)\end{array}$ & $\begin{array}{l}\text { Soil losses } \\
\left(\mathrm{Mg} \mathrm{ha}^{-1} \mathrm{yr}^{-1}\right)\end{array}$ & $\begin{array}{c}\text { C erosion } \\
\left(\mathrm{MgC} \mathrm{ha}^{-1} \mathrm{yr}^{-1}\right)\end{array}$ & Reference \\
\hline \multicolumn{9}{|c|}{ Non-fertilized maize } \\
\hline Kenya & 1000 & 30 & Clayey Alfisol & 80 & 0.02 & 29.0 & 2.4 & \multirow{2}{*}{$\begin{array}{l}\text { Gachene et al. (1997) } \\
\text { this study }\end{array}$} \\
\hline Benin & 1200 & 4 & Sandy loam Ultisol & 20 & 0.28 & 34.0 & 0.3 & \\
\hline \multicolumn{9}{|c|}{ Fertilized maize (or sorghum) } \\
\hline Ivory Coast & 2100 & 7 & Sandy loam Ultisol & 34 & 0.27 & 89.4 & 1.8 & Roose (1980a) \\
\hline Kenya & 1000 & 30 & Clayey Alfisol & 80 & 0.01 & 8.4 & 0.7 & Gachene et al. (1997) \\
\hline Burkina Faso & 800 & 1 & Sandy Alfisol & 13 & 0.25 & 7.3 & 0.2 & Roose (1978) \\
\hline Zimbabwe & 500 & 5 & Sandy Alfisol & $15 ?$ & 0.17 & 20.6 & 0.2 & Moyo (1998) \\
\hline Ivory Coast & 1350 & 3 & Sandy (gravely) Oxisol & 21 & 0.20 & 5.5 & 0.1 & Roose (1980b) \\
\hline Benin & 1200 & 4 & Sandy loam Ultisol & 22 & 0.12 & 9.3 & 0.1 & this study \\
\hline \multicolumn{9}{|l|}{ Maize-mucuna } \\
\hline Benin & 1200 & 4 & Sandy loam Ultisol & 35 & 0.08 & 2.9 & 0.1 & this study \\
\hline
\end{tabular}

a $0-30 \mathrm{~cm}$ 
Roose, 1996). Under non-fertilized maize in Kenya, low runoff rates $\left(0.02 \mathrm{~mm} \mathrm{~mm}^{-1}\right)$ resulted in high soil losses (29 $\mathrm{Mg} \mathrm{ha}^{-1} \mathrm{yr}^{-1}$ ); assuming that the clayey Alfisol in this study had a stable structure with a high infiltration rate, steep slopes $(30 \%)$ probably determined the non-selective transport of aggregates in the absence of adequate groundcover.

Mean annual $\mathrm{C}$ erosion was estimated at $0.3,0.1$ and $0.1 \mathrm{Mg} \mathrm{Cha} \mathrm{yr}^{-1}$ in T, NPK and M treatments, respectively. Though mean soil losses were three times more in NPK than in M, eroded $\mathrm{C}$ was similar in both treatments probably because of high ( $\mathrm{C}$ content in surface soil (which supplies sediments) and higher ( enrichment ratio of sediments in $M$ than in NPK treatments. Indeed, several experiments have indicated that ('enrichment ratio increases with decrease in soil losses (Roose, 1980a, 1980b). Thus, mucuna mulch was less effective in reducing the amount of $C^{\prime}$ erosion than in reducing runoff' and soil losses; but it was very effective in reducing the proportion of topsoil ( $C$ that was eroded, which was much lesser in $M$ than in NPK treatments. This underlines the interest of referring $C$ erosion to topsoil $C^{\prime}$ (enrichment ratio), and to temporal changes in topsoil $\mathrm{C}$.

These data are consistent with those reported in the literature, which showed that $\mathrm{C}$ erosion significantly increased with increase in the product of soil losses and soil $\mathrm{Ct}$ stock $(\mathrm{r}=0.932$, $\mathrm{p}<0.01$; Figure 1, drawn up from Table 5). The data reported herein show that either soil $\mathrm{Ct}$ stock ( $\mathrm{T}$ and NPK) or soil losses (M) were rather small, thus ( erosion was much smaller than in studies from Kenya (high soil Ct stocks on steep slopes) and lvory Coast (humid conditions), where it ranged from 0.7 to $2.4 \mathrm{MgC} \mathrm{ha}^{-1} \mathrm{yr}^{-1}$.

\section{Conclusion}

For this sandy loam Ultisol, relay-cropping of maize and mucuna (M) was very effective in enhancing $\mathrm{C}$ sequestration: change in $\mathrm{Ct}$ stock for $\left(0-40 \mathrm{~cm}\right.$ depth was $+1.3 \mathrm{MgCha}^{-1} \mathrm{yr}^{-1}$ over the 12-year period of the experiment, ranging among the highest rates recorded for the ecoregion. This increase resulted first from the high amount of residue biomass provided by mucuna, which amounted to $10 \mathrm{Mg} \mathrm{DM} \mathrm{ha}{ }^{-1} \mathrm{yr}^{-1}$ ( $83 \%$ aboveground). Mucuna residues, supplying the soil with $\mathrm{N}$, also favoured the production of maize biomass, and total mucuna plus maize residue biomass returned to the soil was about $20 \mathrm{Mg} \mathrm{ha}^{-1} \mathrm{yr}^{-1}$. These results indicate the usefulness of mucuna for SOM management. In contrast, non-fertilized (T) and fertilized continuous maize cultivation (NPK) resulted in -0.2 - and $+0.2-\mathrm{Mg} \mathrm{C}$ ha ${ }^{-1} \mathrm{yr}^{-1}$ change in $\mathrm{Ct}$ stock for $0-40 \mathrm{~cm}$ depth, respectively. Total residue biomass was 8 and $13 \mathrm{Mg} \mathrm{ha}^{-1} \mathrm{yr}^{-1}$, including 77 and $29 \%$ by weeds, respectively. These contributions demonstrate the need for weed biomass sampling, especially when noticeable rainfall occurs beside the cropping season. Weed biomass was negligible in $M$, underlining the potential of mucuna for weed control.

Moreover, the thick mulch produced by mucuna decreased losses by runoff and erosion, which were $0.28,0.12$ and $0.08 \mathrm{~mm} \mathrm{~mm}^{-1}$, and 34,9 and $3 \mathrm{Mg} \mathrm{ha}^{-1} \mathrm{yr}^{-1}$ in T, NPK and M treatments, respectively. Froded $\mathrm{C}$ was estimated at $0.3,0.1$ and $0.1 \mathrm{Mg} \mathrm{C}^{\prime} \mathrm{ha}^{-1} \mathrm{yr}^{-1}$ in $\mathrm{T}, \mathrm{NPK}$ and $M$, respectively. Thus, $C$ erosion was of the same order of magnitude as changes in soil $\mathrm{C}$ stock in treatments vulnerable to erosion ( $\mathrm{T}$ and $\mathrm{NPK}$ ). In contrast, $\mathrm{C}$ erosion under maizemucuna was negligible as compared to changes in soil Ct stock.

Though its benefits on SOM management, weed suppression and erosion control, cropping systems including a legume cover may have an adverse impact from a global change standpoint. Indeed, rough estimates show that $\mathrm{N}_{2} \mathrm{O}$ emissions resulting from $\mathrm{N}$ supply by mucuna may partly offset soil $\mathrm{C}$ storage in $\mathrm{M}$ treatment. In NPK, $\mathrm{N}_{2} \mathrm{O}$ fluxes consecutive to mineral $N$ supply could even offset soil C storage completely. In order to characterize these adverse effects and establish greenhouse gas balances precisely, there is an urgent need for 
accurate field measurements of $\mathrm{N}_{2} \mathrm{O}$ fluxes, especially in cropping systems including legumes.

\section{Acknowledgements}

We thank Barthélémy Ahossi. Maurice Dakpngan, Charles de Gaulle Ghehi. Nestor Gbehi. Branco Sadoyetin and André Zossou for fieldwork. Jean-Yves Laurent and Jean-Claude Marcourel for technical assistance. and ficrard Bourgeon for his comments on a previnus version of the paper. This work was financially supported by a French PROSE grant (CNRSORSTOM program on soil and erosion).

\section{References}

Akobundu. I.O. 1980. Live mulch: a new approach to weed control and crop production in the tropics. p. 377-382. In: Proceedings of the British Crop Protection Conference Weeds, Brighton.

Azontonde, A. 1993. Dégradation et restauration des terres de barre (sols ferrallitiques faiblement désaturés argilo-sableux) au Bénin. Cahiers ORSTOM Série Pédologie 28: 217-226.

Azontonde, A., C. Feller, F. Ganry, and J.C. Rémy. 1998. Le mucuna et la restauration des proprićtés d'un sol ferrallitique au sud du Bénin. Agriculture et Développement 18: 55-62.

Bayer, C. L. Martin-Neto, J. Mielniczuk. C.N. Pillon, and L. Sangoi. 2001. Changes in organic matter fractions under subtropical no-till cropping systems. Soil Science Society of America Journal 65: 1473-1478.

Bouwman, A.F. 1996. Direct emission of nitrous oxide from agricultural soils. Nutrient Cycling in Agroecosystems 46: 53-70.

Carsky, R.J., M. Becker, and S. Hauser. 2001. Mucuna cover crop fallow systems: potential and limitations. p. 111-135. In: G. Tian. F. Ishida, and D. Keatinge (eds), Sustaining Soil Fertility in West Africa, Soil Science Society of America Special Publication No 58, Madison, WI.

Craswell, E.T. and R.D.B. Lefroy. 2001. The role and function of organic matter in tropical soils. Nutrient Cycling in Agroecosystems 61: 7-18.

Dagnélie, P. 1975. Théorie et Méthodes Statistiques. Applications Agronomiques. 2nd edn. Presses Agronomiques de Gembloux. Belgium.

Djegui, N.. P. de Boissezon, and E. Gavinelli. 1992. Statut organique d'un sol ferrallitique du Sud-Bénin sous forêt et différents systèmes de culture. Cahiers ORSTOM Série Pédologie 27: $5-22$.

FAO-ISRIC-ISSS (Food and Agriculture Organization of the United Nations, International Soil Reference and Information Centre. International Society for Soil Science). 1998. World Reference Base for Soil Resources. FAO. Rome.

Feller, C.. A. Albrecht, and D. Tessier. 1996. Aggregation and organic matter storage in kaolinitic and smectitic tropical soils. p. 309-359. In: M.R. Carter and B.A. Stewart (eds.). Structure and Organic Matter Storage in Agricultural Soils. Advances in Soil Science, Lewis, New York

Feller, C. and M.H. Beare. 1997. Physical control of soil organic matter dynamics in the tropics. Geoderma 79: 69-116.

Feller, C., A. Albrecht, E. Blanchart. Y.M. Cabidoche, T. Chevallier, C. Hartmann, V. Eschenbrenner, M.C. Larré-Larrouy, and J.F. Ndandou. 2001. Soil organic carbon sequestration in tropical areas. General considerations and analysis of some edaphic determinants for Lesser Antilles soils. Nutrient Cycling in Agroecosystems 61: 19-31. 
Gachene, C.K.K., N.J. Jarvis, H. Linner, and J.P. Mbuvi. 1997. Soil erosion effects on soil properties in a highland area of Central Kenya. Soil Science Society of America Journal 61: $559-564$.

IPCC (Intergovernmental Panel on Climate Change). 2001. C'limate ('hange 2001: The Scientific Basis. Contribution of Working (iroup 1 to the Third Assessment Report of the $I P C$ C . Cambridge University Press, UK.

Kirchhof, G., and F.K. Salako. 2000. Residual tillage and bush-fallow effects on soil properties and maize intercropped with legumes on a tropical Alfisol. Soil Use and Management 16: 183-188.

Lal, R. 1998. Land use and soil management effects on soil organic matter dynamics on Alfisols in western Nigeria. p. 109-126. In: R. Lal, J.M. Kimble, R.F. Follett, and B.A. Stewart (eds.), Soil Processes und the Carbon Cycle, CRC Press, Boca Raton, FL.

Lal, R. 2000. Land use and cropping systems effects on restoring soil carbon pools of degraded Altisols in Western Nigeria. p.157-165. In: R. Lal, J.M. Kimble, and B.A. Stewart (eds.), Global Climate ('hange and Tropical Ecosystems, CRC Press, Boca Raton, FL.

Le Bissonnais, Y. 1996. Aggregate stability and assessment of soil crustability and erodibility. 1. Theory and methodology. European Journal of Soil Science 47: 425-437.

Merckx, R., J. Diels, B. Vanlauwe, N. Sanginga, K. Denef, and K. Oorts. 2001. Soil organic matter and soil fertility. p. 69-89. In: G. Tian, F. Ishida, and D. Keatinge (eds.), Sustaining Suil Fertility in West Africa. Soil Science Society of America Special Publication No 58, Madison, WI.

Moyo, A. 1998. The effect of soil erosion on soil productivity as influenced by tillage with special reference to clay and organic matter losses. Advances in GeoEcology 31:363-368.

Pieri, C. 1991. Fertility of Soils: A Funure for Furming in the West Africun Savannah. Springer-Verlag, Berlin.

Raunet, M., L. Séguy, and C. Fovet-Rabot. 1999. Semis direct sur couverture végétale permanente du sol: de la technique au concept. p. 41-52. In: F. Rasolo and M. Raunet (eds.), Gestion Agrobiologique des Sols él de's Systèmes de ('ulture, ('IRAD, Montpellier, France.

Roose, E.J. 1978. Dynamique Actuelle de Déux Sols Ferrugineux Tropicaux Indurés sous Sorgho et sous Savane Soudano-Sahélienne - Saria (Haute-Volta): Synthèse des Campagnes 1971-1974. ORSTOM, Paris.

Roose, E.J. 1980a. Dynamique Actuelle d'un Sol Ferrallitique Sablo-Argileux Très Désaturé sous ('ultures et sous Forêt Dense Humide Sub-Equatoriale du Sud de la côte d'lvoire Adiopodoumé: 1964-1975. ORSTOM, Paris.

Roose, E. 1980b. Dynamique Actuelle d'un Sol Ferrallitique (iravillonnaire Issu de Granite sous c'ulture et sous Savane Arbustive Soudanienne du Nord de la Côte d'lvoire Korhoge: 1967-1975. ORSTOM, Paris.

Roose, E: 1996. Land Husbandry, Components and Strategy. FAO Soils Bulletin No 70, Rome.

Roose, E. and R. Bertrand. 1972. Importance Relulive de l'Erosion, du Ruissellement et du Drainage Oblique et Vertical sous une Savane Arbustive de Moyenne Côte d'lvoire Boucuké: 1967-1971. ORSTOM-IRAT, Abidjan.

Roose, E.J. and J. Godefroy. 1977. Pédogenèse Actuelle d'un d'un Sol Ferrallitique Remanié sur Schiste sous Forêt et sous Bananeraie Fertilisée de Basse Côte d'voire. Synthèse de Huil Années d'Observations de l'Erosion, du Drainage e' de l'Activité des Vers de Terre à la Station IRFA d'Azaguié et la Forêt du Téké. ORSTOM-IRFA, Abidjan. 
Sá, J.C.M., C.C. Cerri, W.A. Dick, R. Lal, S.P. Venske Filho, M.C. Piccolo, and B.E. Feigl. 2001. Organic matter dynamics and carbon sequestration rates for a tillage chronosequence in a Brazilian Oxisol. Soil Science Society of America Journal 65: 14861499.

Sanchez. P. 1976. Properties and Management of Soils in the Tropics. Wiley, New York.

Shang, C., and H. Tiessen. 2000. Carbon turnover and carbon-13 natural abundance in organo-mineral fractions of a tropical dry forest soil under cultivation. Soil Scicnce Society of America Journal 64: 2149-2155.

Soil Survey Staff. 1994. Keys to Soil Taxonomy: Gth ed. USDA - Soil Conservation Service, Washington, DC.

Starr. G.C., R. Lal, R. Malone, D. Hothem. L. Owens. J. Kimble. 2000. Modelling soil carbon transported by water erosion processes. Land Degradation and Development 11: 83-91.

Triomphe. B.L. 1996a. Seasonal Nitrogen Dynamics and Long-Term Changes in Soil Properties under the Mucuna/Maize ('ropping System on the Hillsides of Northern Honduras. PhD Thesis. Cornell Iniversity, New York.

Triomphe. B. 1996b. Un système de culture original et performant dans une zone de montagne du tropique humide: la rotation maïs/mucuna au Nord-Honduras, p. 318-328. In: J. Pichot. N. Sibelet, and J.J. Lacoeuilhe (eds.). Fertilité du Milieu et Stratégies Paysannes sous les Tropiques Humides. CIRAD - Ministère de la Coopération. Paris.

Vanlauwe, B.. O.C. Nwoke, J. Diels, N. Sanginga, R.J. Carsky, J. Deckers, and R. Merckx. 2000. Utilization of rock phosphatc by crops on a representative toposequence in the Northern Guinea savanna zone of Nigeria: response by Mucuna pruriens, Lablah purpureus and maize. Soil Biology and Biochemistry 32: 2063-2077.

Voelkner, H. 1979. Urgent needed: an ideal green mulch crop for the tropics. World Crops 31: 76-77.

Wischmeier, W.H., and D.D. Smith. 1978. Predicting Rainfall Erosion Losses: a Guide to Erosion Planning. USDA, Washington, DC. 